\title{
CHEMOSPHERE
}

\section{Ozonation of an azo dye C.I. Remazol Black 5 and toxicological assessment of its oxidation products}

\author{
Chunxia Wang ${ }^{\mathrm{a}}$, Ayfer Yediler ${ }^{\mathrm{b}, *}$, Doris Lienert ${ }^{\mathrm{c}}$, Zijian Wang ${ }^{\mathrm{a}}$, \\ Antonius Kettrup ${ }^{\text {b,c }}$ \\ a State Key Laboratory of Environmental Aquatic Chemistry, Research Center for Eco-Environmental Sciences, \\ Chinese Academy of Sciences, Beijing 100085, PR China \\ ${ }^{\mathrm{b}}$ Institute of Ecological Chemistry, GSF-National Research Center for Environment and Health, \\ Ingolstadter Landstrasse 1, 85764 Neuherberg, Germany \\ ${ }^{\mathrm{c}}$ Chair of Ecological Chemistry, Technical University of Munich, 85350 Freising, Germany
}

Received 8 March 2002; received in revised form 13 March 2003; accepted 25 March 2003

\begin{abstract}
The effect of ozonation (20.5 $\mathrm{mg}^{-1}$ ) on the degradation processes of an azo dye, Remazol Black 5 (RB5; CI) was studied. Conventional parameters such as chemical oxygen demand (COD), total organic carbon (TOC), pH, conductivity, colour removal, biodegradability $\left(\mathrm{BOD}_{5 / 28}\right)$, and toxic potential of the dye and its degradation products were monitored during the process. The results obtained indicated that ozonation is a highly effective way to remove the colour of a corresponding dye solution. However, a considerable organic load still remained as indicated by high COD and TOC residues. The COD, TOC reductions were about $40 \%$ and $25 \%$ for $6 \mathrm{~h}$ ozonation of $2 \mathrm{~g} \mathrm{l}^{-1} \mathrm{RB} 5$ aqueous solution. During the ozonation process the rapid decrease of $\mathrm{pH}$ and the sharp increase of conductivity indicated the formation of acidic by-products and small fragments and ions which were identified by high performance ion chromatography. The $\mathrm{BOD}_{28}$ data revealed that first by-products after partial ozonation (10-150 min) of RB5 were more biodegradable than the parent compound and ozonation can enhance the biodegradability of azo dyes. During the first $150 \mathrm{~min}$ of total $360 \mathrm{~min}$ of oxidation, the formation of first by-products with high toxic potential took place as it could be confirmed by two acute toxicity-screening tests, the bioluminescence test (Vibrio fischerii) and the neutral red cytotoxicity assay (rat hepatoma cells). The significant enhancement of microbial biodegradability after long-term ozonation could also be seen as a decrease of toxic intermediates in correlation with the ozonation time as indicated in $\mathrm{BOD}_{28}$ biological degradation test results.
\end{abstract}

(C) 2003 Elsevier Science Ltd. All rights reserved.

Keywords: Reactive dyes; Ozonation; Acute toxicity; Biodegradability; $\mathrm{BOD}_{5 / 28}$; Oxidation by-products; Bioluminescence test; The neutral red cytotoxicity assay

\section{Introduction}

Due to the rapid change in customers demands textile dyeing and finishing industry is challenged to use high

\footnotetext{
${ }^{*}$ Corresponding author. Fax: +49-89-3187-3371.

E-mail address: yediler@gsf.de (A. Yediler).
}

quantities of dyestuffs, auxiliaries and other chemicals. The worldwide annual production of the dyestuffs amounts to more than $7 \times 10^{5} t$ (Spadaro et al., 1994). Azo dyes are the most widely used commercial reactive dyes and are characterized by nitrogen double bonds $(-\mathrm{N}=\mathrm{N}-)$. They contain between one and four azo groups usually attached to two radicals of which at least one, but usually both, are aromatic groups. The initial 
concentration of these highly structured polymers in batch dyeing ranges from 10 to $70 \mathrm{gl}^{-1}$. In general, $40-90 \%$ of the dye is fixed to the fabric during the dyeing process, depending on the fixation rate of the applied dyestuff (procion or remazol) (Tzitzi et al., 1994; Arslan and Balcioglu, 1999; Moraes de Gomes et al., 2000). The release of dyes into the environment may constitute a small proportion of water pollution, but dyes in effluent are highly visible and undesirable (Nigam et al., 2000). Due to the tightening government legislations as a consequence of growing customers awareness dyestuff manufacturing industry is forced to treat their waste effluent to an increasingly high standard. The Ecological and Toxicological Association of the Dyestuff Manufacturing Industry (ETAD) reported that the highest rates of toxicity $\left(\mathrm{LD}_{50}\right)$ were found amongst basic and diazo direct dyes (Shore, 1996) It is known that brightly colored, water soluble reactive and acid dyes are the most problematic, as they tend to pass through conventional treatment systems unaffected (Moran et al., 1997).

Neither simple chemical nor biological treatment has been proved to be adequate in decolourization and sufficient depletion in organic matter so far (Krull et al., 1998; Koch et al., 2002). Their low BOD $5 /$ COD ratio values (usually less than 0.1 ) indicate their resistance to conventional biological treatment (Liakou et al., 1997). The destruction of toxic pollutants such as biologically recalcitrant compounds in textile wastewater has to be handled in combination of non-biological technologies such as special techniques called advanced oxidation processes (AOPs). Ozone as one of the common oxidation agent has been applied to many fields in water and wastewater treatment and is considered as one of the potential methods for a combined treatment, e.g. oxidative and biological processing, of effluents from textile dyeing and finishing industry (Schultz et al., 1992; Tzitzi et al., 1994; Lopez et al., 1998; Ciardelli and Ranieri, 2001; Robinson et al., 2001; Andreozzi et al., 2003). Ciardelli and Ranieri (2001) report that $30 \mathrm{~g} / \mathrm{m}^{3}$ ozone doses were sufficient to obtain good results in terms of colour removal for contact times of $60 \mathrm{~min}$ for wastewaters from several dyeing and finishing plants. Higher doses did not in- dicate further benefits. Authors confirm that ozonation can be used to remove colour and COD to an extent which is sufficient for water reuse. Moraes de Gomes et al. (2000) submitted textile effluent to the ozonation at $\mathrm{pH} 11$ by an ozone concentration of $14 \mathrm{mgl}^{-1}$ by a treatment time of $60 \mathrm{~min}$. They observed a partial decolourization, a small modification of substrate and some decrease of toxicity.

Although ozone is used increasingly to degrade the recalcitrant compounds still little is known about the reaction intermediates and products formed during ozonation of textile effluents. Our previous investigations indicated that the first by-products after short-term ozonation are not to be underestimated since they might have higher toxic potential than their original compounds (Wang et al., 2002). In the present study a commonly used azo reactive dye, Remazol Black 5 was chosen as a representative model compound to obtain detailed information on the degradation products during various ozonation period and to evaluate their potential toxic effect on microorganisms and rat hepatoma cells by applying $\mathrm{BOD}_{28}$ biological degradation test, and two toxicity assays namely the bioluminescence test and the neutral red (NR) cytotoxicity test.

\section{Material and methods}

The azo reactive dye Remazol (Reactive) Black 5 (RB5, Colour Index), was purchased from BASF, Germany, as a commercially available dye formulation designated as Basilen Schwarz FB, containing RB 5 in $75 \%$ purity. The exact composition of the formulation chemicals representing the rest $25 \%$ of the commercial RB 5 is not exactly known since it is protected by the producer. It is assumed to contain chemicals like salts, detergents, etc. Main characteristics of RB 5 are represented in Fig. 1.

An aqueous solution of RB 5 was prepared in relatively high concentration $\left(C_{\mathrm{dye}}=2 \mathrm{gl}^{-1}\right)$ in order to investigate the effect of ozonation on colour-, COD-, and TOC-removal, on its biodegradability $\left(\mathrm{BOD}_{5 / 28}\right)$, and on the formation of potential toxic oxidation by-products.



Molecular formula: $\mathrm{C}_{26} \mathrm{H}_{21} \mathrm{~N}_{5} \mathrm{O}_{19} \mathrm{~S}_{6} \mathrm{Na}_{4}$; Molecular weight: $991.8 \mathrm{~g} \mathrm{~mol}^{-1}$ Water solubility: $82 \mathrm{~g} \mathrm{l}^{-1}(293 \mathrm{~K})$

Fig. 1. Characteristics of Remazol Black 5 (CI). 


\section{Ozonation}

Ozone was generated from dried air by an ozone generator "Ozon Erzeuger 24 g" of the company Erwin Sander Elektroapparatebau, Ueltzen, Germany. The ozone concentration was determined by an ozone monitor "Ozon Meßgerät" (Erwin Sander Elektroapparatebau, Ueltzen, Germany). Ozonation was performed in a cylindrical glass reactor (volume 1.21 ) by bubbling the ozone/air mixture at a volume stream of $201 \mathrm{~h}^{-1}$ through a sintered glass filter (pore size 50-80 $\mu \mathrm{m}$ ) fixed at the bottom of the reactor into the solution. The ozone concentration, representing the average concentration of commonly used, applied was $20.5 \mathrm{mgl}^{-1}$ (Moraes de Gomes et al., 2000; Ciardelli and Ranieri, 2001; Wu and Wang, 2001).

Samples $(20 \mathrm{ml})$ were withdrawn at defined time intervals and analyzed for UV/VIS-absorbance, chemical oxygen demand (COD), total organic carbon (TOC), $\mathrm{pH}$, conductivity, inorganic/organic anions, and $\mathrm{BOD}_{5 / 28}$. The acute toxicity and cytotoxicity of samples were examined as well.

Decolourization capacity of ozonation process was detected at the maximum visible absorbance wavelength (590 nm) using Varian Cary 1 spectrophotometer. Total organic carbon (TOC) was measured by a Shimadzu model 2000 TOC analyzer. COD determination was conducted using commercially available test kits of the company Machery \& Nagel, Düren, Germany. Anions were analyzed by high performance ion chromatography (HPIC) with a Dionex model 4000I ion chromatograph (Dionex, Sunnyvale, CA, USA) equipped with an IonPac HPICE-AS11 column (Dionex) and operating in suppressed conductivity detection mode. Samples, injected with a volume of $50 \mu \mathrm{l}$ by an automatic sampler, were eluted by a $\mathrm{NaOH} /$ water gradient at a flow rate of $1.5 \mathrm{ml} \mathrm{min}^{-1}$.

Before toxicity screening and conducting the $\mathrm{BOD}_{5 / 28}$ biodegradation test, the collected samples were aerated to ensure that the excess ozone was removed. The $\mathrm{pH}$ of the sample solutions was adjusted to $\mathrm{pH}$ 7.4. The samples for neutral red cytotoxicity assays were filter sterilized by $0.22 \mu \mathrm{m}$ membrane.

\section{Biological degradation $\left(\mathrm{BOD}_{5 / 28}\right)$}

$\mathrm{BOD}_{5 / 28}$ was determined by the oxygen consumption in a closed system (respirometer) during an incubation period of 28 days $\left(\mathrm{BOD}_{28}\right)$ according to the German standard method DIN L22 and the European standard method 294089. Nutrient solutions and $2.5 \mathrm{ml}$ of the effluent of the municipal sewage treatment plant of Munich City (as inoculum) were added to $250 \mathrm{ml}$ of sample solutions in a flask and incubated at $20 \pm 1{ }^{\circ} \mathrm{C}$ in the water bath of a "Sapromat, Typ D" (Fa Voith). The BOD of the samples is calculated via the current of the electrically generated oxygen needed to substitute the consumed oxygen. Triplicates were run for each sample.

\section{Bioluminescence test}

As a pre-toxicity-screening assay, a bioluminescence test was applied to the samples before and after the ozone treatment at different time intervals. All tests were run as duplicates. This test utilizes the inhibition of the bioluminescence of the marine photobacteria Vibrio fischeri as an indication of acute toxicity (Bulich, 1979; Froehner et al., 2000; Jennings et al., 2001). All tests were conducted according to the German standard method DIN 38412; L34; L341, Germany and ISO DIS 11348 on a Dr. LANGE LUMIStox 300 photometer. The marine photobacteria were added to different dilutions of a sample and all vials were allowed to stabilize at $15{ }^{\circ} \mathrm{C}$ for $15 \mathrm{~min}$. After $30 \mathrm{~min}$ incubation luminescence of the solutions was measured. LUMIStox 300 is equipped with color correction facility. Highly colored samples were diluted to meet an extinction below 1800 $\mathrm{mE}$. The results of the bioluminescence test are quantified as dilution factors (GL-values), for which luminescence inhibition of the bacteria is less than $20 \%$ after 30 min exposure. The higher the GL-value, the more toxic is the sample. Luminescence bacteria and all reagents required were also obtained commercially by the above mentioned company.

\section{Neutral red cytotoxicity assay}

The neutral red (NR) cytotoxicity bioassay is a cell survival/viability chemo-sensitivity assay, based on the binding of neutral red, a weakly cationic supravital dye, to the lysosomal matrix of viable cells after their incubation to toxic agents and environmental samples with suspected toxic potential. The procedures employed are those reported by Babich and Borenfreund (1990). Briefly, samples, collected at given time intervals during ozonation, were tested using the H4-IIE rat hepatoma cell line obtained from the American Type Culture Collection. Neutral Red (NR, 3-amino-m-dimethylamino-2-methyl-phenazine hydrochloride) was purchased from Sigma Co.; Dulbecco's MEM was used as cell culture medium. $2.5 \times 10^{3}$ cells were seeded into individual wells of a 96-well microtitre tissue culture plate for $24 \mathrm{~h}$. The medium was then replaced with fresh medium, with or without the addition of various concentrations of samples, using 8-well lanes per concentration. The plate was incubated for three days at $37^{\circ} \mathrm{C}$ and $5 \% \mathrm{CO}_{2}$ (incubator, Heraeus Instruments). $0.4 \%$ NR solution and 1M HEPES buffer (Sigma Co.) were 
added to the medium to final concentrations of 50 $\mu \mathrm{g} \mathrm{ml}^{-1}$ and $20 \mu \mathrm{M}$, respectively. After incubation for an additional 2-4 $\mathrm{h}$ with NR, the absorbance of aqueous dye solution was determined on a Microplate reader (SLT LABINSTRUMENTS, EAR 340 AT, Australia) at $550 \mathrm{~nm}$. The readings of eight replications were averaged and the results expressed as absorbance observed as percentage of control cultures.

\section{Results and discussion}

\subsection{Chemical oxidation}

In Table 1 the results of conventional chemical and physical characterization studies of the aqueous RB5 solution prior to ozonation and after different time intervals of ozonation are summarized.

A rather high dye concentration $\left(2 \mathrm{gl}^{-1}\right)$ was chosen in order to permit the identification of the degradation products as well as a better estimation of their toxic potential. Typical concentrations of an exhausted RB 5 dye bath are considered to be between 0.8 and $2.6 \mathrm{gl}^{-1}$ (Arslan and Balcioglu, 2000; Yediler et al., 2000). As the degradation rate of $\mathrm{RB} 5$ reacting with ozone depends on the dye concentration and on the ozone consumption, much longer ozonation periods $(360 \mathrm{~min})$ were chosen than commonly described $(30-60 \mathrm{~min})$ in the related literature (Moraes de Gomes et al., 2000; Ciardelli and Ranieri, 2001; Wu and Wang, 2001; Koch et al., 2002). Results obtained with the laboratory-scale experiments indicate however that a nearly complete decolourization can be achieved after $3 \mathrm{~h}$ of ozonation with an ozone concentration of $20.5 \mathrm{mgl}^{-1}$. Due to the production of organic and inorganic acid anions, the $\mathrm{pH}$ decreased for the duration of ozonation from $\mathrm{pH} 6.1$ to 2.3. Throughout the whole process the conductivity increased (Table 1).

The COD reduction was more efficient than the reduction in TOC (Fig. 2). A 44\% COD removal rate was

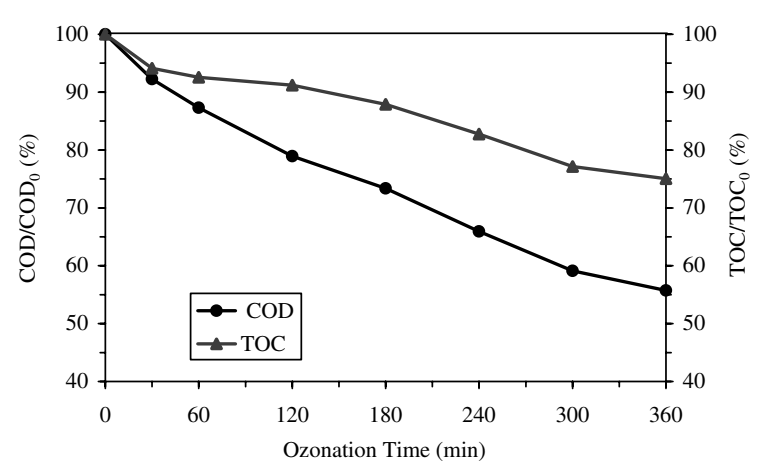

Fig. 2. Remaining COD and TOC (in \%) in aqueous solution of Remazol Black $5\left(C_{\text {dye }}=2 \mathrm{~g} \mathrm{l}^{-1}\right.$; ozone concentration $=20.5$ $\mathrm{mgl}^{-1}$ ) as a function of ozonation time.

obtained after $360 \mathrm{~min}$ of ozonation. The corresponding TOC removal rate was $25 \%$ under identical operational conditions. The relatively low COD and TOC reduction was most likely due to the fact that structured dye molecules are oxidized by ozonation to small organic molecular fragments, such as acetic acids, aldehydes, ketones, etc., not being completely mineralized under the described oxidative conditions (Rice, 1981). These small molecules contribute considerably to the COD that cannot be completely removed by the ozonation reaction. However, they are easily digested by the activated sludge processes (Lin and Lin, 1993). As indicated by Singer (1990) even in the presence of excess ozone, the reaction does not result in the complete mineralization of organic carbon to carbon dioxide. The TOC/ $\mathrm{TOC}_{0}$ ratio is helpful to assess the mineralization rate but the obtained TOC values may not represent the total TOC concentrations due to the losses of volatile compounds of the aqueous dye solution i.e. formaldehyde, acetaldehyde into the gaseous stream during the ozonation process (Koch et al., 2002).

To obtain detailed information on the reaction processes during ozonation, the resulting oxidation prod-

Table 1

Ozonation of Remazol Black $5\left(C_{\text {dye }}=2 \mathrm{~g}^{-1}\right.$; ozone concentration $\left.20.5 \mathrm{mg} \mathrm{l}^{-1}\right)$ : conventional parameters

\begin{tabular}{llllllll}
\hline$T(\mathrm{~min})$ & $\begin{array}{l}A / A_{0} \\
590 \mathrm{~nm}(\%)\end{array}$ & $\begin{array}{l}\mathrm{pH} \text { at } \\
21{ }^{\circ} \mathrm{C}\end{array}$ & $\begin{array}{l}\text { Cond. at } 21^{\circ} \mathrm{C} \\
(\mu \mathrm{S} / \mathrm{cm})\end{array}$ & $\begin{array}{l}\mathrm{COD}^{*} \\
\left(\mathrm{mg} \mathrm{O}_{2} / \mathrm{l}\right)\end{array}$ & $\begin{array}{l}\mathrm{COD} / \mathrm{COD}_{0} \\
(\%)\end{array}$ & $\begin{array}{l}\mathrm{TOC}^{*} \\
(\mathrm{mg} / \mathrm{l})\end{array}$ & $\begin{array}{l}\mathrm{TOC}^{\mathrm{TTOC}}{ }_{0} \\
(\%)\end{array}$ \\
\hline 0 & 100.0 & 6.1 & 1510 & 1615 & 100.0 & 41.8 & 100.0 \\
30 & 47.3 & 3.3 & 1761 & 1490 & 92.3 & 39.3 & 94.1 \\
60 & 21.4 & 3.1 & 2159 & 1410 & 87.3 & 38.7 & 92.6 \\
120 & 4.2 & 2.7 & 2610 & 1275 & 78.9 & 38.1 & 91.2 \\
180 & 0.5 & 2.6 & 3130 & 1185 & 73.4 & 36.7 & 87.9 \\
240 & 0.3 & 2.4 & 3650 & 1065 & 65.9 & 34.6 & 82.8 \\
300 & 0.1 & 2.4 & 4120 & 955 & 59.1 & 32.2 & 77.1 \\
360 & 0.0 & 2.3 & 4530 & 900 & 55.7 & 31.4 & 75.1 \\
\hline
\end{tabular}

${ }^{*}$ Dilution ratio 1:10. 


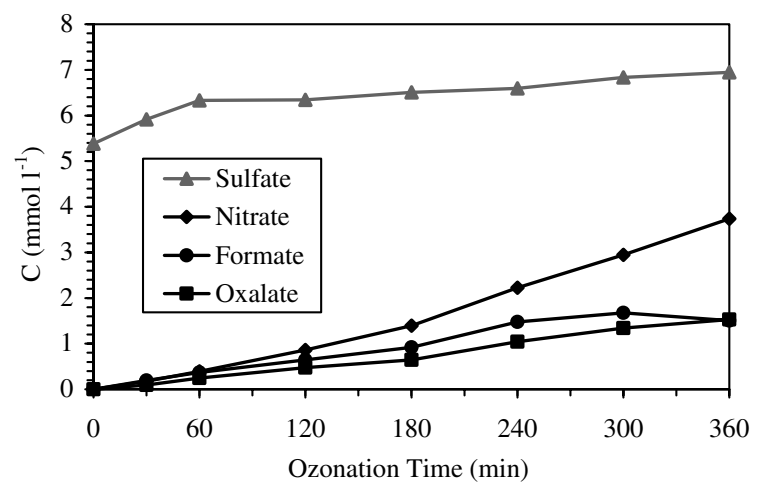

Fig. 3. Concentrations of sulfate, nitrate, formate, and oxalate during ozonation of Remazol Black $5\left(C_{\text {dye }}=2 \mathrm{~g} \mathrm{l}^{-1}\right.$; ozone concentration $=20.5 \mathrm{mg} \mathrm{l}^{-1}$ ).

ucts were determined. Sulfate, nitrate, formate and oxalate were identified as main oxidation fragments of RB 5 after 360 min ozonation. Their concentrations during the ozonation are shown in Fig. 3. Formation of nitrate is presumably the result of the oxidation and cleavage of the azo and amino groups. Oxidation and cleavage of the sulfonic acid groups results in increase of sulfate. The high initial sulfate concentration of the aqueous RB5 solution is caused by the content of sulfate salts within the dye formulation. Zhang et al. (2002) obtained similar results during the oxidative degradation of purified, hydrolyzed azo dye, Reactive Red 120 (CI), after 150 min treatment with an ozone concentration of 12.8 $\mathrm{mg} 1^{-1}$.

Parallel to the decrease of the COD, biodegradability, measured as $\mathrm{BOD}_{5}$ and $\mathrm{BOD}_{28}$, improved significantly. These contrary effects result in a strong increase of the $\mathrm{BOD} / \mathrm{COD}$ ratio. The initial $\mathrm{BOD}_{5}$ and $\mathrm{BOD}_{28}$ values of $2 \mathrm{~g}^{-1} \mathrm{RB} 5$ solution are very low (only 0.2 and $1.4 \%$ of the chemical oxygen demand, respectively) as listed in Table 2. After $30 \mathrm{~min}$ of ozonation, the $\mathrm{BOD}_{5} /$ $\mathrm{COD}_{t}$ ratio increased by a factor of 8 , after $360 \mathrm{~min}$ of ozonation the $\mathrm{BOD}_{5}$ was determined to be $13.8 \%$ of the chemical oxygen demand. The biodegradation test of 28 days revealed an enhancement of the $\mathrm{BOD}_{28} / \mathrm{COD}_{t}$ ratio from $1.4 \%$ of the initial dye solution to about $30 \%$ for

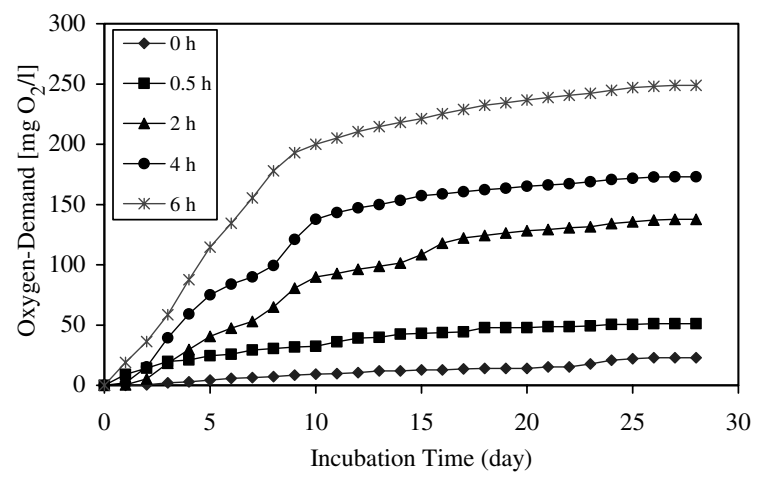

Fig. 4. Oxygen consumption of aqueous dye solutions of Remazol Black 5 during 28 days Sapromat test $\left(C_{\text {dye }}=2 \mathrm{~g} \mathrm{l}^{-1}\right.$; ozone concentration $=20.5 \mathrm{mgl}^{-1}$; different ozone contact times).

the dye solution. This phenomena was probably a result of increased metabolic activity due to the presence of the more easily degradable compounds which seem to be less toxic especially for the samples treated by ozone longer than 120 min as shown in Fig. 4.

The sample containing the parent compound almost resists biodegradation throughout the incubation time. It is obvious that the biomass can hardly acclimatize to the xenobiotic water components of the parent compound. The aqueous dye solution collected after $30 \mathrm{~min}$ ozonation seem to contain still inhibitory compounds resulting from incomplete biodegradation throughout the incubation time of 28 days. As the oxidation continues a tendency in increased oxygen consumption of the biomass can be observed most probably caused by the presence of the easily biodegradable compounds and to a lesser extent by adaptation of the bacteria (Krull et al., 1998; Yediler et al., 2000; Zhang et al., 2002).

It is unknown in which way the oxidation products and other formulation chemicals present in the RB 5 effect the aquatic microbial activity. Therefore the standardized bioluminescence assay with Vibrio fischeri and the neutral red cytotoxicity assay were performed for the assessment of the acute toxicity of the oxidation by-products after partial ozonation of the dye solution. As it can be seen in Fig. 5 the comparison of the results

Table 2

Ozonation of Remazol Black 5 ( $C_{\text {dye }}=2 \mathrm{gl}^{-1}$; ozone concentration $\left.20.5 \mathrm{mgl}^{-1}\right)$ : biodegradability studies

\begin{tabular}{lllcccr}
\hline$t(\mathrm{~min})$ & $\begin{array}{l}\mathrm{COD}_{t} \\
\left(\mathrm{mg} \mathrm{O}_{2} / \mathrm{l}\right)\end{array}$ & $\begin{array}{l}\mathrm{COD}_{t} / \mathrm{COD}_{0} \\
(\%)\end{array}$ & $\begin{array}{l}\mathrm{BOD}_{5} \\
\left(\mathrm{mg} \mathrm{O}_{2} / \mathrm{l}\right)\end{array}$ & $\begin{array}{l}\mathrm{BOD}_{5} / \mathrm{COD}_{t} \\
(\%)\end{array}$ & $\begin{array}{l}\mathrm{BOD}_{28} \\
\left(\mathrm{mg} \mathrm{O}_{2} / \mathrm{l}\right)\end{array}$ & \multicolumn{1}{c}{$\begin{array}{l}\mathrm{BOD}_{28} / \mathrm{COD}_{t} \\
(\%)\end{array}$} \\
\hline 0 & 1631 & 100 & 4 & 0.2 & 23 & 1.4 \\
30 & 1548 & 95 & 25 & 1.6 & 51 & 3.3 \\
120 & 1187 & 73 & 41 & 3.5 & 138 & 11.6 \\
240 & 1094 & 67 & 75 & 6.8 & 173 & 15.8 \\
360 & 831 & 51 & 115 & 13.8 & 249 & 29.9 \\
\hline
\end{tabular}




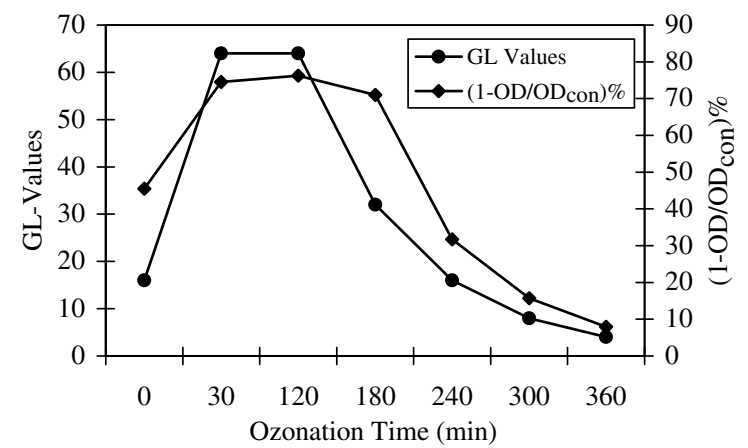

Fig. 5. Toxic potential of Remazol Black 5 measured by bioluminescence test (GL-value) and neutral red cytotoxicity assay before and after different ozonation intervals $\left(C_{\text {dye }}=2 \mathrm{~g} \mathrm{l}^{-1}\right.$; ozone concentration $=20.5 \mathrm{mg} \mathrm{l}^{-1}$ ).

of bioluminescence and neutral red cytotoxicity assay show a good agreement indicating the potential toxicity of the ozonated dye solution. The inhibitory effect on the bioluminescence of the bacteria is increasing as a function of ozonation time most probably due to the formation of first by-products with high toxic potential which seems to be destroyed by further ozonation process. The results of NR assay, based on the uptake of neutral red and its accumulation in the lysosomes of viable uninjured cells, also demonstrated an increased toxicity during the first 120 min of ozonation. Results of both assays confirm the assumption of the partial oxidative treatment of aqueous dye solutions with ozone produces toxic intermediates with harmful effects on organisms. The $30 \mathrm{~min}$ bioluminescence assay applied to the untreated dye solution indicates a moderate toxicity potential characterized by a GL-value of 16 . The GLvalue increases to 64 demonstrating a significant higher toxic effect of the solution for ozonation periods of 30 $120 \mathrm{~min}$. A drastic decrease in toxicity $(\mathrm{GL}-\mathrm{value}=4)$ with prolonged ozonation time of $360 \mathrm{~min}$ reflects the disappearance of the toxic compounds.

Applications of the NR assay for the acute toxicity testing of xenobiotics have been extensive including chemicals like organometals (Babich and Borenfreund, 1988; Babich et al., 1989), surfactants (Borenfreund and Puerner, 1985), food additives (Babich and Borenfreund, 1990), etc. To apply this assay by the toxicity assessment of a widely used azo reactive dye proves to be promising as our results show. Untreated dye solutions indicated a relative cytotoxicity of $45 \%$, whereas samples after 30 min ozonation had a significant higher relative toxicity of $75 \%$. Further ozonation within a time interval of 180 min could not reduce the toxic potential of the solution. To achieve a reduction in the toxicity of the ozonated samples ozonation periods of $>240 \mathrm{~min}$, leading to a relative toxicity of $10 \%$, were required. The observed increase of the toxic potential of the ozonated dye solution is most probably caused by the formation of toxic intermediates which are obviously destroyed by further ozonation. Glaze (1986) has noted that the classes of organic by-products that might be formed during ozonation process are of special interest in water treatment because of their potential health effects. These are suspected to be organic peroxides, unsaturated aldehydes, and epoxides. Unsaturated aldehydes are known to be strong hepatotoxins, and epoxides are potential carcinogens. According to Lopez et al. (1998), the oxidation intermediate products of azo dyes might be nitro-aromatics as a result of the oxidative breakage of the molecules by ozone. The authors identified the structures of some by-products by HPLC, IC, and GCMS and determined the formation of toxic intermediates of an azo reactive dye, namely Fast-Violet-B during the ozonation process. Identification of ozone by-products and the toxic intermediates, by HPLC-MS, IC, of azo dyes is a subject of further studies of our group too.

\section{Conclusions}

The high volume of coloured wastewater in textile finishing industry demands a special treatment and evaluation of the ecotoxic effects of the process effluents released into environment. A single treatment technique cannot eliminate all contaminants in these effluents. Ozone treatment proves to be very effective for complete removal of colour but provides only partial reduction of COD and TOC. Oxidative treatment of the dyebaths with ozone, however, enhances the biodegradability of biorefractory compounds. Therefore, a combined treatment of ozonation and biological degradation might be a choice for the treatment of dye bath effluents. However, for colour removal in exhausted dye baths longer ozonation periods have to be applied as also described by various authors (Gähr et al., 1994; Arslan and Balcioglu, 2000) increasing the treatment costs. In addition to that short-term ozonation with a $1 / 3$ contact time, as shown in this study, of the total period results in a significant increase of toxicity caused by first toxic byproducts.

The results obtained demonstrate that ozonation as a partial step of a combined treatment concept is a potential technique for decolorization and biodegradability enhancement of wastewater containing reactive azo dyes provided that the appropriate ozonation period is chosen. Before the industrial application it is recommended to evaluate the required ozonation time which is enough to destroy not only colour but also the toxic first byproducts.

Therefore, a combined treatment, involving oxidative and biological methods, of either the total dyehouse effluents or pre-selected process lines suitable for re-use purposes containing less colour and COD, should be 
used to achieve the best economical and ecological result, and to ensure the methods acceptance by the industry.

\section{Acknowledgements}

The authors wish to thank the VW-Foundation (Project-Nr.: II/72 146), the National Natural Science Foundation of China (Grants 20037010), the Chinese Academy of Sciences (KZCX2-410) and the German Federal Ministry of Education and Research (BMBF) for the financial support of this research work. This work has been conducted at GSF-National Research Center for Environment and Heath, Institute of Ecological Chemistry, Neuherberg, Germany.

\section{References}

Andreozzi, R., Caprio, V., Marotta, R., Vogne, D., 2003. Paracetamol oxidation from aqueous solutions by means of ozonation and $\mathrm{H}_{2} \mathrm{O}_{2} / \mathrm{UV}$ system. Water Res. 37, 9931044.

Arslan, I., Balcioglu, A., 1999. Oxidative treatment of simulated dyehouse effluent by UV and near-UV light assisted Fenton's reagent. Chemosphere 39, 2767-2783.

Arslan, I., Balcioglu, I.A., 2000. Effect of common reactive dye auxiliaries on the ozonation of dyehouse effluents containing vinylsulphone and aminochlorotriazine dyes. Desalination 130, 61-71.

Babich, H., Borenfreund, E., 1988. Structure-activity relationships for diorganotins, chlorinated benzenes, and chlorinated anilines established with bluegill sunfish BF-2 cells. Fundam. Appl. Toxicol. 10, 295-301.

Babich, H., Martin-Alguacil, N., Borenfreund, E., 1989. Comparisons of the cytotoxicities and fibroblasts in vitro. In: Goldberg, A.M. (Ed.), Alternative Methods in Toxicology VII. Mary Ann Leibert Inc, New York, pp. 153-167.

Babich, H., Borenfreund, E., 1990. Application of the neutral red cytotoxicity assay to in vitro toxicology. ATLA 18, 129144.

Borenfreund, E., Puerner, J.A., 1985. Toxicity determined in vitro by morphological alterations and neutral red absorption. Toxicol. Lett. 24, 119-124.

Bulich, A.A., 1979. Use of luminescent bacteria for determining toxicity in aquatic environment. In: Markings, L.L., Kimerle, R.A. (Eds.), Aquatic Toxicity, STP 667. American Society for Testing and Materials, PA, pp. 98-106.

Ciardelli, G., Ranieri, N., 2001. The treatment and reuse of wastewater in the textile industry by means of ozonation and electroflocculation. Water Res. 35, 567-572.

Froehner, K., Backhaus, T., Grimme, L.H., 2000. Bioassays with Vibrio fischeri for the assessment of delayed toxicity. Chemosphere 40, 821-828.

Gähr, F., Hermanutz, F., Oppermann, W., 1994. Ozonationan important technique to comply with new German laws for textile waste water treatment. Water Sci. Technol. 30, $255-263$.
Glaze, W.H., 1986. Chemistry of ozone, by-products and their health effects. Ozonation: Research Advances and Research Needs, AWWARF, Denver, Colorado. June, 1986.

Jennings, V.L.K., Rayner-Brandes, M.H., Bird, D.J., 2001. Assessing chemical toxicity with the bioluminescent photobacterium (Vibrio fischeri): A comparison of three commercial systems. Water Res. 35, 3448-3456.

Koch, M., Yediler, A., Lienert, D., Insel, G., Kettrup, A., 2002. Ozonation of hydrolyzed azo dye reactive yellow 84 (CI). Chemosphere 44, 109-113.

Krull, R., Hemmi, M., Otto, P., Hempel, D.C., 1998. Combined biological and chemical treatment of highly concentrated residual dyehouse liquors. Water Sci. Technol. 38, 339-346.

Liakou, S., Pavlou, S., Lyberatos, G., 1997. Ozonation of azo dyes. Water Sci. Technol. 35, 279-286.

Lin, S.H., Lin, Chi M., 1993. Treatment of textile waste effluents by ozonation and chemical coagulation. Water Res. 27, 1743-1748.

Lopez, A., Ricco, G., Mascolo, G., Tiravanti, G., Di Pinto, A.C., Passino, R., 1998. Biodegradability enhancement of refractory pollutants by ozonation: a laboratory investigation on an azo-dyes intermediate. Water Sci. Technol. 38, 239-245.

Moraes de Gomes, S., Freire Sanches, R., Duran, N., 2000. Degradation and toxicity reduction of textile effluent by combined photocatalytic and ozonation processes. Chemosphere 40, 369-373.

Moran, C., Hall, M.E., Howell, R.C., 1997. Effects of sewage treatment on textile effluent. J. Soc. Dyers. Colour 113, 272274.

Nigam, P., Armour, G., Banat, I.M., Singh, D., Marchant, R., 2000. Physical removal of textile dyes and solid state fermentation of dye-adsorbed agricultural residues. Biosour. Technol. 72, 219-226.

Rice, R.G., 1981. Ozone for the treatment of hazardous materials. AIChe Symp. 209, 79.

Robinson, T., McMullan, G., Marchant, R., Nigam, P., 2001. Remediation of dyes in textile effluent: a critical review on current treatment technologies with a proposed alternative. Bioresor. Technol. 77, 247-255.

Shore, J., 1996. Advances in direct dyes. Indian J. Fib. Text. Res. 21, 1-29.

Schultz, G., Herlinger, H., Gähr, F.U., Lehr, Th., 1992. Oxidativer Abbau von Farbstoffen durch Ozon. Textilpraxis Int. 11, 1055-1062.

Singer, P.C., 1990. Assessing ozonation research needs in water treatment. Report to the AWWA Research Foundation, Denver, Colo. Journal AWWA 1990, October, pp. 78-88.

Spadaro, J.T., Isabelle, L., Renganathan, V., 1994. Hydroxyl radical mediated degradation of azo dyes: evidence for benzene generation. Environ. Sci. Technol. 28, 1389-1393.

Tzitzi, M., Vayenas, D.V., Lyberatos, G., 1994. Pretreatment of textile industry waste waters with Ozone. Water Sci. Technol. 29 (9), 151-160.

Yediler, A., Lienert, D., Koch, M., Kettrup, A., GermirliBabuna, F., Karatas, Ö., Insel, G., Dulkadiroglu, H., Orhon, D., 2000. Appropriate Technologies for the Minimization of Environmental Impact from Industrial Wastewaters-Textile Industry, A Case Study (AZ.: II/72 146). Final Report. Submitted to Volkswagen-Foundation, Germany. 
Wang, C.X., Yediler, A., Lienert, D., Wang, Z., Kettrup, A., 2002. Toxicity evaluation of reactive dyestuffs, auxiliaries and selected effluents in textile finishing industry to luminescent bacteria Vibrio fischeri. Chemosphere 46, 339344.
Wu, J., Wang, T., 2001. Ozonation of aqueous azo dye in a semi-batch reactor. Water Res. 35, 1093-1099.

Zhang, F., Yediler, A., Liang, X.M., Kettrup, A., 2002. Ozonation of the purified hydrolyzed azo dye reactice red 120 (CI). J. Environ. Sci. Health A 37, 707-713. 